\title{
Identification of a Saxitoxin Biosynthesis Gene with a History of Frequent Horizontal Gene Transfers
}

\author{
Ralf Kellmann - Troco Kaan Mihali • \\ Brett Anthony Neilan
}

Published online: 21 February 2009

(C) Springer Science+Business Media, LLC 2009

Erratum to: J Mol Evol (2008) 67:526-538

DOI: $10.1007 / \mathrm{s} 00239-008-9169-2$

The names of two authors of this article (Troco Kaan Mihali and Brett Anthony Neilan) were misspelled in the print and online versions published previously. Their names are presented correctly here.

The online version of the original article can be found under doi: 10.1007/s00239-008-9169-2.

R. Kellmann ( $\square)$

Department of Molecular Biology, University of Bergen,

P.O. Box 7803, 5020 Bergen, Norway

e-mail: ralf.kellmann@mbi.uib.no

T. K. Mihali · B. A. Neilan

School of Biotechnology and Biomolecular Sciences,

University of New South Wales, Sydney NSW 205, Australia 